\title{
How Do We Think about Death?
}

\section{----A Cultural Glance of Superstitious Ideas from Chinese and Western Ghost Festivals}

\author{
Wenli Zhang \\ The College of International Exchange \\ Yanshan University, Qinhuangdao City, China 066004 \\ E-mail: wenliz2007@hotmail.com
}

\begin{abstract}
Superstitious ideas are always in people's life in spite of scientific and technological advancement. Hungry Ghost Festival in China, Halloween in some western countries and Day of the Dead in Mexico are three religious festivals which are observed every year. They reveal people's idea about ghosts and spirits after death. They also include doctrines which imprison people's minds and thoughts. This thesis mainly talks about the three religious ideas about death and spirits from Buddhism, Taoism, and Christian.
\end{abstract}

Keywords: Halloween, Hungry Ghost Festival, Day of the Dead, Religious, Death

\section{The origin and celebration of the three ghost festivals}

\subsection{Halloween and Day of the Dead}

Halloween is one of the oldest holidays with origins going back thousands of years. The holiday we know as Halloween has had many influences on many cultures over the centuries, from the Celtic festival of Samhain, to the Roman's Pomona Day, to the Christian holidays of All Saints and All Souls Days.

At present, Halloween doesn't have superstitious color at all. It has become children's holiday. The Pumpkin Patches are celebration symbols and "Trick or Treating" is their slogan of Halloween. Many pictures of Halloween are lovely and kindly, and most of them are funny, such as, witches, black cats. The old story has been forgotten by people constantly. Halloween has been a joyful festival in people's heart. In a word, Halloween has become an ordinary and seasonal holiday for the westerners.

Day of the Dead, falls on November $1^{\text {st }}$ and November $2^{\text {nd }}$, celebrated mainly in Mexico and by people of Mexican heritage living in the US and Canada. Many people believe that during Day of the Dead, it is easier for the souls of the departed to visit the living. Celebrations can take a humorous tone, as celebrants remember funny events and anecdotes about the departed. Some people believe that possessing the items of the dead can bring good luck. Many people get tattoos or have dolls of the dead to carry with them. They also clean their houses and prepare the favorite dishes of their deceased loved ones to place upon their altar.

People in Mexico viewed death as the continuation of life. Instead of fearing death, they embraced it. To them, life was a dream and only in death did they become truly awake. They didn't separate death from pain, wealth from poverty. They have a humorous and optimistic attitude toward death.

\subsection{Hungry Ghost Festival}

Much like Halloween in western culture, Chinese people believe that on the 15th of July of the lunar calendar, the gates of hell are thrown open, releasing hungry ghost to wander the earth in search of food and taking revenge upon those who wronged them in life. This month-long festival is known as the Hungry Ghost Festival. It is also called Zhongyuan Festival in Taoism, Yu Lan Pen Festival in Buddhism.

The Buddhist would hold the Yu Lan Pen Festival in memory of their forefathers. There was a popular folk tale about how the monk, Mu Lian, saved his mother from suffering. Mu Lian had great magic power. After her death, his mother fell into the mouth of a hungry ghost and all the food she wants to eat turned into flames. Mu Lian had no idea to save his mother, so he asked Buddha for help. Buddha told him the Yu Lan Pen canon and asked him to save his mother on the 15th day of the 7th lunar month with the help of Yu Lan Pen.

The Taoist doctrine holds that the universe was generated by three basic elements: heaven, earth and water. The official of earth named Lord Qingxu absolves sins. He was born in July 15, which is called Zhongyuan Festival. During this festival, he would release the deceased from sufferings, and those who have committed sins could also pray for 
absolution.

Activities at Hungry Ghost Festival include offering food and burning hell money and incense in front of the house to please the visiting ghosts and spirits as deities and ancestors. Other activities include burning and releasing miniature paper boats and lanterns on water, which signifies "giving directions to the lost ghosts".

No matter which side they are on, Chinese citizens have never shown much interest in ghosts. The streets that night are empty in some cities, as few dare leave their house. They say if a ghost finds you in the street and follows you back home, your family will have bad luck all year. All in all, people should be very careful during the Chinese ghost festival; they have to keep away from ghosts and not offend them. It's really not as much fun as Halloween.

\section{Religious Ideas toward death and after-death spirit}

\subsection{Views of Christianity}

In Western countries, Christianity is a very important religion. They have many views on death and spirits.

(1) The death of the human body doesn't mean that all the things have vanished. The death is not the end of the life, but is the beginning of another life.

(2) We survive in the world as a guest. It is temporary.

(3) We should hope for the happy hometown, which is in the heaven and is prepared for us by the God.

(4) Human's soul doesn't extinguish forever.

(5) The people can get the life again after millennium, and the rebirth is the work of the Holy Ghost. It is not the work of humans.

(6) The samara reincarnation is extent form of the human life.

The Christian think that there is coexistent time of the human and god. And the human has soul. There was a judicial procedure after people died. If the person believes in the Christ before his death, he or she can depend on Christ to enter the eternal life. The world may end in one day, but the person can live in the new world, which is made by the God, because the life is eternal there.

\subsection{Views of Buddhism}

In China, The ghost's world is actually made by Buddhism, such as, 18 hells and reincarnation. Buddhism thinks that the ghost was one of six kinds. In other words, after the people died, it was possible to ascend to the heaven, to continue to the people's life, to drop for the domestic animal, to go to hell, to become hungry ghost, to go to asura. It is no doubt that dead people are able to turn into ghosts, but the probability is only $1 / 6$.

\subsection{Views of Taoism}

Taoism does not fear death. "Life and death are like day and night." The book of Chuang Tse says,"Death and life have the same root, like twins." For that reason when we have life, death exists.

In Taoism, the energy of life has two parts, the energy of the Yin and the energy of the Yang. The spirit is Yang when a person is alive and when his spirit dies changes to Yin. Yin is the soul and can leave the body when the person dies, but the Yang energy can be preserved. So, Death is nothing but a state of energy, it does not exist in a fixed form; when the soul dies and leaves the body, it will no longer have a fix shape. Yin energy cannot be seen as we see a person.

That's why Taoism considers life as the best thing, because each person can decide about their life. They encourage people to take advantage of their life so that it can be lived healthy, prolonged and perfected.

\section{Superstitious Thoughts of People}

"Step on a crack and break your mother's back," children can be heard chanting as they carefully jump over every crack on the sidewalk. Adults tend to think of superstitions as childish or even uneducated beliefs--and they may be. However, superstitions abound all over the world, each influenced by the cultures of different people.

\subsection{Superstitions in Western Countries}

One of the top stories on a local news channel in Dallas, is the growing demand for statues of St. Joseph. The story reports that

When it comes time to sell a house, some homeowners rely on a statue of St. Joseph. A centuries-old tradition claims that burying a statue of St. Joseph in the yard helps homes sell faster.

Wherever there is a religion, there is a superstition. Superstitious are very deeply in people's mind. In the past, superstitions endangered the people and society. At the moment, superstitions still exist in the society. There are kinds of superstitions in people's life. Some are accepted, others are objected. At the same time, the superstitions produce an effect on the people and society. Here are some superstitions that are pretty famous and are every day examples: 


\subsubsection{An apple a day keeps the doctor away.}

3.1.2. Getting out of bed with left foot first brings bad-luck.

3.1.3. Spit on a new baseball bat before using it for the first time to make it lucky.

3.1.4. If you blow out all the candles on your birthday cake with the first puff you will get your wish.

3.1.5. Before slicing a new loaf of bread, make the sign of the cross on it.

3.1.6. Friday, 13th is the most dreadful day and bring misfortune. Also, If 13 people sit down at a table to eat, one of them will die before the year is over. The number $\underline{13}$, believed to be unlucky, has been skipped over at a horse stable

3.1.7. The devil can enter your body when you sneeze. Having someone say, "God bless you," drives the devil away

3.1.8. How you start the year is how you will end it.

3.1.9. When someone dies, windows must be opened to let the soul out.

\subsection{Superstitions in China}

Looking back into Chinese history, superstitions have been playing an important role as a part of Chinese culture although some people think that's silly and ignorance. Since Liberation, our economic potentiality is expanding step by step, and the scientific cultural level is enhancing day by day. But, the superstitious thoughts are always in the society, and there are many superstitions in China from the past to the present which always affect people's life for a long time. Such as, Feng Shui, Ren Qi, and Temples.

\subsection{1. "Feng Shui"}

The ancient art of feng shui has been practiced in China for thousand of years. In China, traditional buildings (like the Forbidden City in Beijing) were designed according to feng shui principles. In ancient China, the Emperor would consult his imperial advisors regarding political, military and personal issues such as:

- the building of imperial palaces, burial sites and temples

- the building of new cities and public infrastructures

- selecting of auspicious dates for worshipping rituals to seek blessing from heaven for a good harvest and for peace of the kingdom

- the waging of war and the directional movement of troops

There is also a popular saying that a person who enjoys good fortunes and karma will live in a house with good feng shui.

\subsection{2. "Ren Qi"}

Very often, most people tend to overlook the physical feng shui of oneself. A person with good physical feng shui has strong Ren Qi. These are confident people who possessed strong interpersonal skills, which enable them to create new opportunities from their networking, in return enable them to obtain support from important people. To take a holistic approach, it is equally important to create a good feng shui for the house and also for oneself.

\subsubsection{Temples}

China has been an agricultural country. The superstitions originated in the village. The grave of farmer's ancestors are built in there. Many people said that ghosts haunted at night. If some crops are attacked by locusts, the people think that the ghost makes trouble. Owing to the long drought, the crops have failed, but the people think that the God are punishing them. So there are many temples in China, and many people can worship the Buddha at temple every year. Chinese people believe that the ghost and the God are ubiquitous.

\subsubsection{Other Superstitions}

1) In modern apartments, there is always a big mirror in the bathroom, and it is inevitable for us not to look in the mirror when we have a wash before going to bed. Some other people hung a mirror at their door or window to drive away ghosts.

2) If a big fire or a serious flood broke out, you would have a big fortune the next day. On the contrary, if you got a great deal of money in your dream, you'd better be careful the following days, as it is said that you will probably lose your fortune in any form.

3) Standing the chopsticks straightly in the rice bowl or put a empty bowl upside down is a taboo since it is a way to memorize the death.

4) The use of number 4 is minimized or avoided wherever possible because the Chinese word for 4 , sì, sounds nearly the same as the word for death, sǐ. Mobile telephone numbers with 4 in them sell for less. 


\section{Conclusion}

Not easily swept away are superstitions in general. Maybe one reason they have been able to survive the changing world is due to their adaptability. People use superstitions to explain the things they can't control, such as love, life and death. Superstitions also relieve the anxiety these things might cause. In like manner, the children might hold onto a favorite stuffed toy or blanket for comfort, or a college student might wear a "lucky" piece of clothing while taking a test.

Halloween, Hungry Ghost Festival and Day of the Death are linked with ghosts. They originate in different religions, and spread different superstitious thoughts in some western countries and China. Through the three festivals, we can see superstitions vary immensely throughout the world, and their propagation depends on local folklore, legends, and circumstances.

People in Western countries believe in eternal life after death, death is not the end but beginning of a new life. God will help them to live happily and eternally there. Chinese people believe in life more than death. They choose to make their life beautiful. The ghosts are created by people for revenge. That also encourages people who alive to be kind to others and lesson their sins during their life time so that they won't be hunted by ghosts. An old Chinese saying says: Never be afraid of the ghost knocking at your door at midnight if you are a kind person.

From the different ways of thinking about death, we can enjoy the big culture difference between China and some Western countries. This help make life a bit more interesting, like salt in food, it give flavor to a culture, and one must agree that the world-wide culture is certainly flavorful.

\section{References}

Duan, Zhihui. (2006). Western death and philosophy, Beijing. Beijing University Press.

Freud, Sigmund. (1997). Interpretation of Dreams. Wordsworth Edition Ltd.

Fu, Peirong. (2006). Philosophy and human life. Beijing, Renmin University of China Press.

Geng, Weizhong. (2006). Western traditional culture and festival. Taiyuan, Shuhai Press.

Gong, Mu. (2007). Taoism Philosophy. Changchun Press.

Guo, Huo. (2006). The making of Fengshui. Beijing, Huaxia Press.

Hu, Kai-min. (2002). TAOISM. Beijing: Foreign Language Press.

Li, Zheng-shuan. (2006). Thesis Design and Writing Guide for English Majors. Beijing: Peking University Press.

Stevenson Ian. (1966). M.D. Twenty Cases Suggestive of Reincarnation. American Society for Psychical Research.

Tian, Zhen. (2002). The world's three religious and Chinese culture. Beijing, Religious and Culture Press.

Waley ,Arthur. (Translator 1997). Lao-Tzu Tao Te Ching. Wordsworth Edition Ltd.

Wu, Kunru. (2005). Human life Philosophy. Beijing, Renmin University of China. 